\title{
THE INFLUENCE OF THE SOCIAL
}

\section{CAPITAL ON BUSINESS PERFORMANCE:}

\section{AN ANALYSIS IN THE CONTEXT OF}

\section{HORIZONTAL BUSINESS NETWORIS}

Revista de Administração Mackenzie, v. I4, n. 3 (2013)

[RETRACTED ARTICLE] The influence of the social capital on business performance: an analysis in the context of horizontal business networks

OLIVEIRA, J. F.

After several contacts with the author, without a defense manifestation, and careful consideration by the Special Commission of Remarkable Personalities appointed by the Mackenzie Presbyterian University's Rectorship, the following article has been retracted in whole by RAM. Revista de Administração Mackenzie:

OLIVEIRA, J. F. The influence of the social capital on business performance: an analysis in the context of horizontal business networks. Revista de Administração Mackenzie, São Paulo, v. I4, n. 3, p. 209-235, 2013, edição especial. DOI: IO.I590/ Si678-69712013000300009.

Once it was evidenced that such article contains data, results and excerpts originally published in the doctoral thesis:

WEGNER, D. Governança, Gestão e Capital Social em redes horizontais de empresas: uma análise de suas relações com o desempenho das empresas participantes. 20II. 204f. Tese (Doutorado em Administração de Empresas)-Universidade Federal do Rio Grande do Sul, Porto Alegre, 20ıı. 
- RAM, REV. ADM. MACKENZIE, V. 14, N. 3, Ed. Especial • SÃO PAULO, SP • MAIO/JUN. 2013 • ISSN 1518-6776 (impresso) • ISSN 1678-6971 (on-line) • Submissão: 14 jan. 2012. Aceitação: 18 jan. 2013. Sistema de avaliação: às cegas dupla (double blind review). UNIVERSIDADE PRESBITERIANA MACKENZIE. Valmir Emil Hoffmann (Ed. Seção), Walter Bataglia (Ed.), p. 209-235.

\title{
THE INFLUENCE OF THE SOCIAL
}

CAPITAL ON BUSINESS PERFORMANCE:

\author{
AN ANALYSIS IN THE CONTEXT OF
}

HORIZONTAL BUSINESS NETWORIKS

JAYR FIGUEIREDO DE OLIVEIRA

Doutor em Educação pela Pontifícia Universidade Católica de São Paulo (PUC-SP). Pesquisador do Departamento de Administração, Análise e Tecnologia da Informação da Escola de Administração de Empresas de São Paulo da Fundação Getulio Vargas (Eaesp-FGV). Rua São Vicente de Paula, 501, Santa Cecília, São Paulo - SP - Brasil - CEP 01229-010

E-mail: jayr.oliveira@gvmail.br

Este artigo pode ser copiado, distribuído, exibido, transmitido ou adaptado desde que citados, de forma clara e explícita, o nome da revista, a edição, o ano, e as páginas nas quais o artigo foi publicado originalmente, mas sem sugerir que a RAM endosse a reutilização do artigo. Esse termo de licenciamento deve ser explicitado para os casos de reutilização ou distribuição para terceiros. Não é permitido o uso para fins comerciais. 


\section{ABSTRACT}

Based on the arguments of Nahapiet and Ghoshal (1998), this article analyzes the relation between the social capital of entrepreneurs participating in horizontal networks and their companies' performance. A survey of 21 8 business people from 34 horizontal business networks found that the absolute number of contacts of an entrepreneur within the network, the diversity and quality of the relationships and the cognitive similarity positively influence company performance. The results also show that entrepreneurs participating in horizontal networks have access to high levels of relevant information for their businesses, from the social capital developed within the network. The main theoretical contribution of this paper is that it confirms the relevance of social capital in business performance, thus confirming, in the context of inter-organizational networks, the studies by Ahuja (2000), McFadyen and Cannella (2004), Smith, Collins and Clark (2005), Tsang (2005), and Liao and Welsch (2003). As a contribution to a managerial practice, the results show that network managers can create mechanisms to encourage the development of the entrepreneurs' social capital by promoting the creation and strengthening of ties, with positive consequences for business performance.

\section{KEVWORDS}

Social capital; Interorganizational networks; Horizontal business networks; Business cooperation; Performance.

\section{INTRODUCTION}

Sociological, technological and economic transformations, mainly referring to the last 30 years, have produced a scenario that benefits inquiries on the relationship between State, companies and society. Amid this new outline, various 
implications may be pointed out, as for instance: market internationalization, company increase in size and influence, state-control intervention to undo social welfare state, increasing search for expertise, among other things (CASTELLS, I999).

Against this background, criteria for efficiency and success estimates of enterprises, consider not only the economical characteristics, but also the social, cultural, and environmental aspects (SANTOS, et al., 20II). Besides that, with society itself lobbying, companies also started to undertake a major responsibility towards society's welfare, thus supplying guarantees, which were formerly linked solely to the State. Such guarantees are nowadays called Social Responsibility (SANTOS; SILVA, 20IO).

Facing these factors, the model mentioned by Uzzi (1996) becomes essential to understand the role of social capital and society's organizational characteristics, as well as cultural, in order to upgrade society's efficiency through simplified coordinated actions. Being that the fundamental presupposition of the social capital theory relies on the economic as well as on the political sense, for voluntary cooperation is a condition to aim common goals.

The economic definition of social capital refers to rules that promote confidence and reciprocity in economy, according to Putnam (2002). This stated economic definition is comprised through networks, civil organizations, and through shared confidence between people, product of their own social interaction. Regarding the social capital study, it is important to understand the nature and mechanics of a practical community.

Usually social capital refers to the implicit value on the internal and external connections of a social network, however, a great range of definitions interrelated to the term are commonly found. These definitions have a tendency to share the central thought, that social networks have an economic value (GARGIULO; BANASSI, 2000). In the same way a screwdriver, as a sample of physical capital, or school education, as the builder of human capital, can improve productivity for human beings and organizations. Social contacts and the way these relate with themselves are also factors of economic development (AMARAL; RI, 20II).

On the other hand, interorganizational networks (IONs) are strongly emphasized within the academic environment due to its capability to contribute to companies' performance and competitiveness. Especially with regard to micro and small enterprises, cooperation is a relevant strategy because of those companies' competitive limitations and the difficulties that arise from a highly competitive market. While some studies analyze the direct economic gains that derive from cooperation, others seek to understand additional benefits that cooperation can bring in terms of information and knowledge exchange among the participants (CHILD, 200I; HOLMQVIST, 2003). The IONs are important environments for entrepreneurs to have contact with diverse knowledge, information sources and accumulated experiences to be shared with one another (INKPEN, I996). 
A long term continuity of IONs is linked to a generation of results, which could have never been obtained individually by participants. Investing time and resources on a cooperative activity could only make sense, case it is submitted either with a positive or even a potentially constructive cost/benefit ratio (NOHRIA; ECLES, I992). As a result, participators are only kept active and concerned throughout cooperation; meanwhile they obtain a performance that seems satisfactory to them. Theoretically, the network aims to offer the same apprenticeship opportunities and resource access to all of their members, preventing thus a meaningful benefit and performance asymmetry, which could be faced as negative by participants, and even lead to a cooperative relationship detachment.

The social capital is built through the relationships an individual develops, and that give him/her access to different resources, initially held by his/her contacts. It tends to be harder for individual entrepreneurs to create networks that allow them the access to relevant information for their businesses. On the other hand, one of the main characteristics of cooperation within horizontal networks is exactly to put together entrepreneurs from the same segment, who face similar problems, or who have already developed specific solutions for those problems. Therefore, it seems to be evident that entrepreneurs who participate in IONs have bigger chances to develop their social capital and, as a consequence, to obtain resources that potentialize their companies' performance.

Set on this premise, the purpose of this paper is to analyze the relation between the social capital of entrepreneurs participating in horizontal networks and their companies' performance. Estimates show that during the last decade, in Brazil, between 800 and 1.000 horizontal networks and business centrals were created (SEBRAE, 2008; SEDAI, 20IO), both due to public fomenting programs and initiatives coming from the entrepreneurs interested in enhancing their businesses.

In addition to this introduction, the article is structured through other five sections. The first segment presents a conceptual base on social capital and corporate cooperation. The second segment describes the employed research method, variables implementation, samples, modes of gathering, and data processing. Empirical research results are submitted at the third segment. The fourth and fifth segments deal with discussions on the outcomes and final considerations with the theoretical and operational implications of the research.

\section{SOCIAL CAPITAL}

One of the benefits of forming an interorganizational network is that it enables contact among different companies, leading to what Coleman (I998) calls 
deep interactions amongst social actors. Those interactions create a complex web of social networks that make possible the exchange of information and the acquisition of skills, culminating in what Burt (1997), and Nahapiet and Ghoshal (I998) call the social capital. The main proposition of the social capital theory is that relationship networks are valuable because they make it possible for their members to obtain resources from one another through connections created in the networks. Nahapiet and Ghoshal (1998) define social capital as the sum of current and potential resources available that come from an individual's or a social unit's relationship network.

According to Nahapiet and Ghoshal (I998) and Tsai and Ghoshal (1998), social capital plays an important role in facilitating for the companies to acquire and create knowledge. Furthermore, due to a more significant social capital, some companies get - to a certain extent - an advantage over the others. As stated by Nahapiet (2008), academics that study social capital affirm that the people and organizations with better performances are better in accessing and taking advantage of the resources and opportunities that their contacts and relationships make available.

Inkpen and Tsang list four important factors to obtain new knowledge from a relationship network: a) there must be some opportunity to combine and exchange skills (accessibility to social knowledge); b) all parts must be open to the possibility of exchanging knowledge, and confident that it will be possible to develop new skills; c) all parts must be motivated to develop some knowledge, even though they don't know if it will actually happen, and even though they don't know the value of that knowledge; d) it's vital that the parts be capable not only of recognizing the value of new knowledge and information, but also of absorbing it and putting it into practice. Participating in an interorganizational network can favor and potentialize at least the first factor.

Empirical studies show that the social capital has positive effects on corporate performance. Leana and Pil (2006), for example, observed the effects of social capital on corporate performance and learned that there is a positive relation between both of them. Geletkanycs and Hambrick (I997) analyzed the external ties of businesspeople from two different industries (food and technology) and concluded that the relationship networks (or social capital) those people have are important sources of information and knowledge that complement their own experience and affect the organization's performance. Mu, Peng and Love (2008) researched the presence of Chinese software companies in contact networks and discovered that weaker relations help the companies create initial relationships that will later be developed into strong ties and into sharing skills that are hardly accessible. Network relationships are a corporate skill that is extremely hard to copy because they are complex, idiosyncratic, and socially built. 
The social capital consists of three dimensions: structural, relational and cognitive. Those dimensions are addressed in the following three subsections and, starting from them, this research's hypotheses will be drawn.

\section{STRUCTURAL DIMENSION}

The structural dimension of social capital is the pattern of connection among the actors; to whom and how a determinate actor relates. Among the principal scopes of this dimension is the presence or absence of ties amongst the actors. The configuration of the network is also very important; it analyzes its measures regarding depth, connectivity and hierarchy (NAHAPIET; GHOSHAL, I998). Other authors mention as elements of this dimension: the amount of contacts an actor has (UZZI; GILLESPIE, 2002; McFADYEN; CANNELLA Jr., 2004; SMITH; COLLINS; CLARK, 2005), the diversity of those contacts, the configuration and stability of the network (INKPEN; TSANG, 2005), and the position of an actor in the contact network, meaning with whom he/she has contact and how this contact happens (LESSER, 2000).

One of the main measures of the structural dimension of social capital is the number of people to whom an individual is directly connected (AHUJA, 2000). Connecting to many people leads to benefits such as the access to exclusive information, the access to more information and a quicker access to that information (SMITH; COLLINS; CLARK, 2005). Additionally, the diversity of contacts is very important. The heterogeneity of knowledge that different people have allows them to combine and exchange resources, raising the companies' probability of increasing its value by interacting with the social network.

Considering all the presented arguments, formal interorganizational networks are spaces where actors have the opportunity to develop the structural dimension of their social capital. The argument of the social capital's structural dimension is that quantity of and diversity in the relationships are key features in defining the access to more resources, which, in turn, can be used to achieve better performances (NAHAPIET; GHOSHAL, I998; UZZI; GILLESPIE, 2002; INKPEN; TSANG, 2005). In this sense, entrepreneurs that participate in interorganizational networks and establish more contacts with other participants of different profiles have bigger chances to access relevant resources and, as a consequence, improve their results. These theoretical notes about the structural dimension of social capital can be divided into two research hypotheses:

Hypothesis Ia: The quantity of contacts an entrepreneur has in a horizontal network is positively related to his/her business' performance. 
Hypothesis Ib: The diversity of contacts an entrepreneur has in a horizontal network is positively related to his/her business' performance.

\section{RELATIONAL DIMENSION}

In the relational dimension of social capital the focus becomes the content and the characteristics of the relationships. It refers to each one of the individual relationships among one actor and all the others, concerning its intensity (GRANOVETTER, I973), multiplicity - meaning how many roles an actor plays in that relationship - and implicit rules (LARSON; STARR, I993). Mc Fadyen and Cannella Jr. (2004) highlight, also, that the frequency of interactions amongst actors is very important to tighten their relationships.

Two actors might have equivalent positions in similar networks (structural dimension), but if they hold different emotional and personal relationships with other network members, their interactions will differ in important aspects (NAHAPIET; GHOSHAL, I998). Liao and Welsh (2003) also affirm that entrepreneurs that show more trust and that are seen as more trustable are more likely to use their relationships in their favor. Therefore, the relational dimension of social capital is based not on the structure, but on the behavior. The key aspects of this dimension include trust, reliability, norms and sanctions, obligations, and expectations.

Inkpen and Tsang (2005) point out the importance of trust between an entrepreneur and his/her social network, due to the influence of this trust on their willingness to share knowledge. The presence of strong ties among the partners - deriving from mutual knowledge and repeated transactions - is very important to potentialize knowledge exchange. Kale, Singh and Perlmuttar (2000) show a positive relation between the strength of the ties and the learning results in alliances. In another study, Leana and Pil (2006) emphasize that, within a contact network, members who trust each other tend to share information that is not available outside their circle of trust.

Literature uses many elements to identify the relational dimension of social capital: the strength of relationships (McFADYEN; CANELLA Jr., 2004; SMITH; COLLINS; CLARK, 2005), the trust and intimacy actors have among them (INKPEN; TSANG, 2005; NAHAPIET; GHOSHAL, I998), and the reciprocity of the actors (NAHAPIET; GHOSHAL, I998). Granovetter (I973) defends that the strength of a relationship depends on different factors, such as the frequency of interactions, the emotional intensity bonding the actors, the intimacy, and the reciprocity they share. Based on this, the second hypothesis of this research was drawn: 
Hypothesis 2: The relational dimension of an entrepreneur's social capital is positively related to his/her business' performance.

\subsection{COGNITIVE DIMENSION}

The third dimension of social capital, as proposed by Nahapiet and Ghoshal (I998), is the cognitive dimension. Is consists of the interpretations and representations that are shared (TSAI and GHOSHAL, I998), as well as the systems of meaning among the parts (NAHAPIET; GHOSHAL 1998). Inkpen and Tsai (2005) point out two important features of this dimension: the objectives, and the culture that the network members share. Nahapiet (2008) adds that the cognitive dimension refers to representations and systems of meaning shared by actors who either make their social exchanges available, or restrict them. When the objectives and strategies of a horizontal network are clearly outlined and known by all the members, there will be a common comprehension of what is intended and what the available means that can be used in order to reach those goals are.

According to Inkpen and Tsai (2005), communication among different actors is the first step towards resources exchange, and it requires a minimal sharing of the parts' meaning and context. In interorganizational networks, developing relations with other participants can lead to sharing values and meaning, strengthening the relationships and creating a beneficial cycle. The network managers can influence the creation of a shared meaning through specific actions and management practices, such as the creation of forums to discuss the goals and mission of that network and to outline the values and concepts for that group, creating foundations for a shared vision and common objectives.

The elements of this dimension that are used in empirical researches are the existence, among the actors, of: common vision and objectives (INKPEN; TSANG, 2005; TSAI; GHOSHAL, I998); common language and ideas (NAHAPIET; GHOSHAL, I998); and a common history (NAHAPIET; GHOSHAL, I998). The existence of common objectives and ways of thinking among actors causes them to be seen as more reliable and less likely to act opportunistically, which can ultimately make it easier to access knowledge and information, as

216 stated by Tsai and Ghoshal (1998). This argument is tested through the following research hypothesis:

Hypothesis 3: The cognitive dimension of an entrepreneur's social capital is positively related to his/her business' performance.

The analytic model of the research and its hypotheses is presented in Figure I: 


\section{FIGURE I}

\section{ANALYTIC MODEL OF THE RESEARCH AND HYPOTHESES}

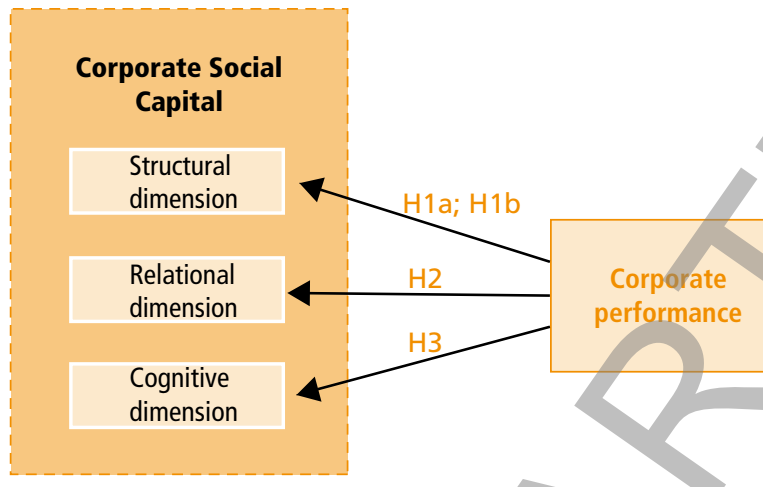

Source: author's own.

\section{RESEARCH METHOD}

To reach the proposed objectives, a quantitative study - specifically a confirmatory survey - was chosen. A quantitative study is proper for the case as it makes it possible to find relations between variables by analyzing a significant number of individuals. Before using the research questionnaire, a validation process was held with the help from entrepreneurs from interorganizational networks, all located in the city of São Paulo. In February and March 2oro, eight horizontal networks experts were interviewed, and the data collection instruments were developed and verified to ensure their accordance with the proposed objectives, based on Santaolària and Diéguez's propositions (2005). The participants were conveniently chosen based on their potential for contributing: four organizational consultants who supported the creation and development of horizontal networks, two managers of corporate networks and two academics who research interorganizational cooperation.

With those experts' participation, variables' items were adapted and the first version of the questionnaire was drafted and tested in two rounds on entrepreneurs who participate in horizontal networks. The entrepreneurs indicated which questions were unclear or unrealistic. They also indicated questions they didn't feel comfortable to answer. Inconsistencies were eradicated and the final draft of the questionnaire was applied to 30 companies as a scale validation process, leading to results that confirm the questionnaire's internal consistence. 


\subsection{VARIABLES OPERATIONALIZATION}

The variable 'social capital' was operationalized into the three dimensions suggested by Nahapiet and Ghoshal (I998) and presented according to the analytic model of research: structural, relational and cognitive (Table I).

The structural dimension was measured by asking the entrepreneurs how many contacts they have inside a horizontal network, i.e., with how many other entrepreneurs they discuss aspects related to their own businesses, competitors, suppliers, and strategies. Also within the structural dimension, they were asked about the diversity of those contacts, regarding knowledge and information.

In the questions about the relational and cognitive dimensions of social capital, the entrepreneur was asked to talk specifically about the contacts he listed in the structural dimension question. If he/she had informed about five entrepreneurs of his/her network (structural dimension), he/she should report the quality of their relationship (the existing trust in their honesty, capability, reciprocity, and proximity in social relations), and how similar were their objectives and vision.

TABLE I

OPERATIONALIZATION OFTHE VARIABLE "SOCIAL CAPITAL"

\begin{tabular}{|c|c|c|}
\hline DIMENSION & NUMBER OF ITEMS & CRONBACH'S ALPHA \\
\hline $\begin{array}{l}\text { Structural dimension - } \\
\text { number of contacts }\end{array}$ & $\begin{array}{l}1 \text { item, based on Smith, Collins and Clark } \\
\text { (2005) }\end{array}$ & - \\
\hline $\begin{array}{l}\text { Structural dimension - } \\
\text { diversity of contacts }\end{array}$ & 1 item, developed by the researcher & - \\
\hline Relational & $\begin{array}{l}5 \text { items developed by the researcher and } \\
\text { adapted from Leana and Pil (2006), and } \\
\text { Smith, Collins and Clark (2005) }\end{array}$ & .785 \\
\hline Cognitive dimension & $\begin{array}{l}3 \text { items, developed by the researcher and } \\
\text { adapted from Leana and Pil (2006), and Tsai } \\
\text { and Ghoshal (1998) }\end{array}$ & .815 \\
\hline
\end{tabular}

Source: Adapted from Nahapiet and Ghoshal (I998).

From those three dimensions, an aggregate variable of an entrepreneur's social capital was created, as done in Leana and Pil's research (2006). In order to accomplish that, the absolute number of contacts he/she has was divided into six 
categories, making it possible to aggregate it to the other items (Cronbach's alpha .707).

Dess and Robinson's research (1984) shows that the subjective measures of corporate performance are correlated to the absolute measures. However, absolute measures are always preferable. In this study, the performance of the companies that participate in the network was analyzed based on four performance dimensions, in accordance with the balanced scorecard methodology - finances, customers, learning and innovation, and internal processes -, gathering measures pointed out in studies about corporate networks and alliances (VERSCHOORE, 2008; ADAM, 2006; MOHR; SPEKMAN, I994; MJOEN; TALLMANN, I997). The reasons for choosing a broad conjunct of dimensions are: the multidimensional characteristic of organizational performance, the difficulties in measuring network companies' results, and the need to go beyond the financial measures. The performance dimensions, number of items, and respective Cronbach's alpha numbers are shown in Table 2.

\section{TABLE 2}

OPERATIONALIZATION OF THE VARIABLE

"CORPORATE PERFORMANCE"

\begin{tabular}{lcc}
\hline & VARIABLE: PERFORMANCE OF THE COMPANIES PARTICIPATING IN A NETWORK \\
\hline DIMENSION & NUMBER OF ITEMS & CRONBACH'S ALPHA \\
\hline Finances & 3 items & .669 \\
\hline Customers & 2 items & .888 \\
\hline Learning and innovation & 2 items & .858 \\
\hline Internal processes & 2 items & .883 \\
\hline
\end{tabular}

Source: Dess e Robinson (1984).

An aggregate variable was generated from the four performance dimensions: “Corporate performance”, with Cronbach's alpha of .864.

\subsection{SAMPLING}

According to data from the Brazilian agency for support to micro and small enterprises (SEBRAE, 2008) and from the secretary for development and international relations of the state of Rio Grande do Sul, Brazil (SEDAI, 20Io), there are between 800 and I,000 corporate horizontal networks in Brazil, in several different market segments. One of the biggest challenges is to try to access the participating entrepreneurs and the information about those networks - the ins- 
titutions that support them don't disclose their database and most of the networks have no websites with contact information.

Initially, a database was generated based on online researches, gathering approximately 2,200 companies associated to 75 horizontal networks from all over the country.

The data was collected through online and printed questionnaires from May thru September 20Io. Three rounds of e-mails were sent inviting entrepreneurs to participate in the research, followed by phone calls to reinforce the importance of their answering the questionnaire. In the companies easily accessible by the researcher, printed questionnaires were left and then picked up personally by the researcher. The questionnaires did not include personal identification of the respondent. In total, 269 companies from 49 networks answered the questionnaire, 7I of which received it printed. From the total, the companies with less than two years of participation in a network were excluded, as well as those with incomplete questionnaires, resulting in a sample of 218 companies from 34 different horizontal networks (Table 3).

\section{TABLE 3}

\begin{tabular}{lcccc} 
& & SAMPLING & & \\
\hline \multicolumn{1}{c}{ SEGMENT } & $\begin{array}{l}\text { NUMBER OF } \\
\text { NETWORKS }\end{array}$ & $\%$ & $\begin{array}{c}\text { NUMBER OF } \\
\text { COMPANIES }\end{array}$ & $\%$ \\
\hline $\begin{array}{l}\text { Construction } \\
\text { materials }\end{array}$ & 8 & 23.5 & 43 & 19.7 \\
\hline $\begin{array}{l}\text { Supermarkets } \\
\text { Pharmacies }\end{array}$ & 7 & 20.6 & 45 & 20.6 \\
\hline $\begin{array}{l}\text { Bookstores/ } \\
\text { stationers }\end{array}$ & 4 & 11.8 & 36 & 16.5 \\
\hline $\begin{array}{l}\text { Furniture and } \\
\text { household } \\
\text { appliances }\end{array}$ & 3 & 8.8 & 15 & 6.9 \\
\hline $\begin{array}{l}\text { Electrical } \\
\text { materials }\end{array}$ & 2 & 8.8 & 23 & 10.6 \\
\hline $\begin{array}{l}\text { Sports materials } \\
\text { Auto parts }\end{array}$ & 1 & 5.9 & 11 & 5.0 \\
\hline $\begin{array}{l}\text { Courses and } \\
\text { trainings }\end{array}$ & 1 & 2.9 & 5 & 2.3 \\
\hline
\end{tabular}




\section{TABle 3 (Conclusion)}

SAMPLING

\begin{tabular}{lcccc}
\hline \multicolumn{1}{c}{ SEGMENT } & $\begin{array}{l}\text { NUMBER OF } \\
\text { NETWORKS }\end{array}$ & $\%$ & $\begin{array}{l}\text { NUMBER OF } \\
\text { COMPANIES }\end{array}$ & $\%$ \\
\hline $\begin{array}{l}\text { Informatics } \\
\text { products }\end{array}$ & 1 & 2.9 & 5 & 2.3 \\
\hline Shoes & 1 & 2.9 & 5 & 2.3 \\
\hline Gas stations & 1 & 2.9 & 5 & 2.3 \\
\hline Auto shops & 1 & 2.9 & 5 & 2.3 \\
\hline TOTAL & $\mathbf{3 4}$ & $\mathbf{1 0 0}$ & $\mathbf{2 1 8}$ & $\mathbf{1 0 0}$ \\
\hline
\end{tabular}

Source: author's own.

There was no statistic difference between the printed and the electronic versions of the questionnaire. Most of them were answered by the company's owner or by a manager (98\%) to avoid imprecise answers due to the lack of knowledge of the respondent.

\subsection{DATA PROCESSING}

To analyze the data, the research hypotheses were tested using correlation and regression techniques. Correlation was chosen because it allows the researcher to verify whether or not there is a linear relation between two variables, i.e., whether or not alterations in one variable affect the other one (MALHOTRA, 200I). Regarding regression, it was chosen to check if there is any statistically significant influence of one variable over another, making it possible to reject or confirm the presented hypotheses.

One of the main fundaments of the parametric statistic techniques is the normal distribution of data. The data's normality can be indicated by the Kolmogorov-Smirnov test and by the analysis of the variables' kurtosis and asymmetry value, according to Hair et al. (2005). While analyzing the data, the researcher noticed the presence of asymmetry and kurtosis in most variables' distribution, being the asymmetry index $\mathrm{Z}$ above the critical level indicated by Hair et al. (2005). In order to adjust this asymmetry, the data was transformed according to Cox-Box method, proposed by Osborne (2010). This method consists of a series of transformations that includes and broadens the traditional options of data transformation, facilitating the choice for the transformation that results in better data adjustment. The procedure was performed in all variables, and for each 
one of them, the most adequate transformation technique was chosen. Subsequently, the variables were standardized in accordance to the procedure proposed by Kline (2005), which consists of converting variables values into ZI scores. The standardization was necessary to put all variables in the same scale and, consequently, enable comparisons among them.

\section{RESULTS ANALISYS}

The research hypotheses, based on social capital theory, proposed that a formal horizontal network is a space where entrepreneurs can develop social networks of contacts. These networks enable them to access and exchange resources, information, and knowledge that could difficultly be accessed in the market. They also provide entrepreneurs with early and privileged access to restrict information (NAHAPIET; GHOSHAL, I998).

The structural dimension of social capital was measured through two questions: the number of contacts and the diversity of those contacts' knowledge and information. In the first question, the respondents should indicate, within the network, the entrepreneurs with whom they held a closer relationship and with whom they discuss aspects related to business strategies, competitors, suppliers, technologies etc. In average, the respondents have 7.5 contacts inside their network (with a standard deviation of 5.3), indicating the existence of a social network within the formal network.

Comparing the number of contacts indicated by the entrepreneurs and the total number of associates in each network, the conclusion is that, in average, an entrepreneur's close relationships represent approximately 31\% of the total of associates. It means that an entrepreneur's social network consists of less then one-third of the total number of participants of the formal network. Even though the horizontal networks are built as universal networks (TODEVA, 2006), in practice the social relationships with potential to exchange resources and information are significantly less than the total of the network's associates.

The hypotheses about the relation between entrepreneurs' social capital and their businesses' performance were tested through correlation and regression analyses, as represented in Tables 4 and 5 .

Hypothesis Ia: The structural dimension of social capital - quantity of contacts an entrepreneur has is positively related to his/her business' performance.

Hypothesis Ib: The structural dimension of social capital - diversity of contacts an entrepreneur has is positively related to his/her business' performance. 


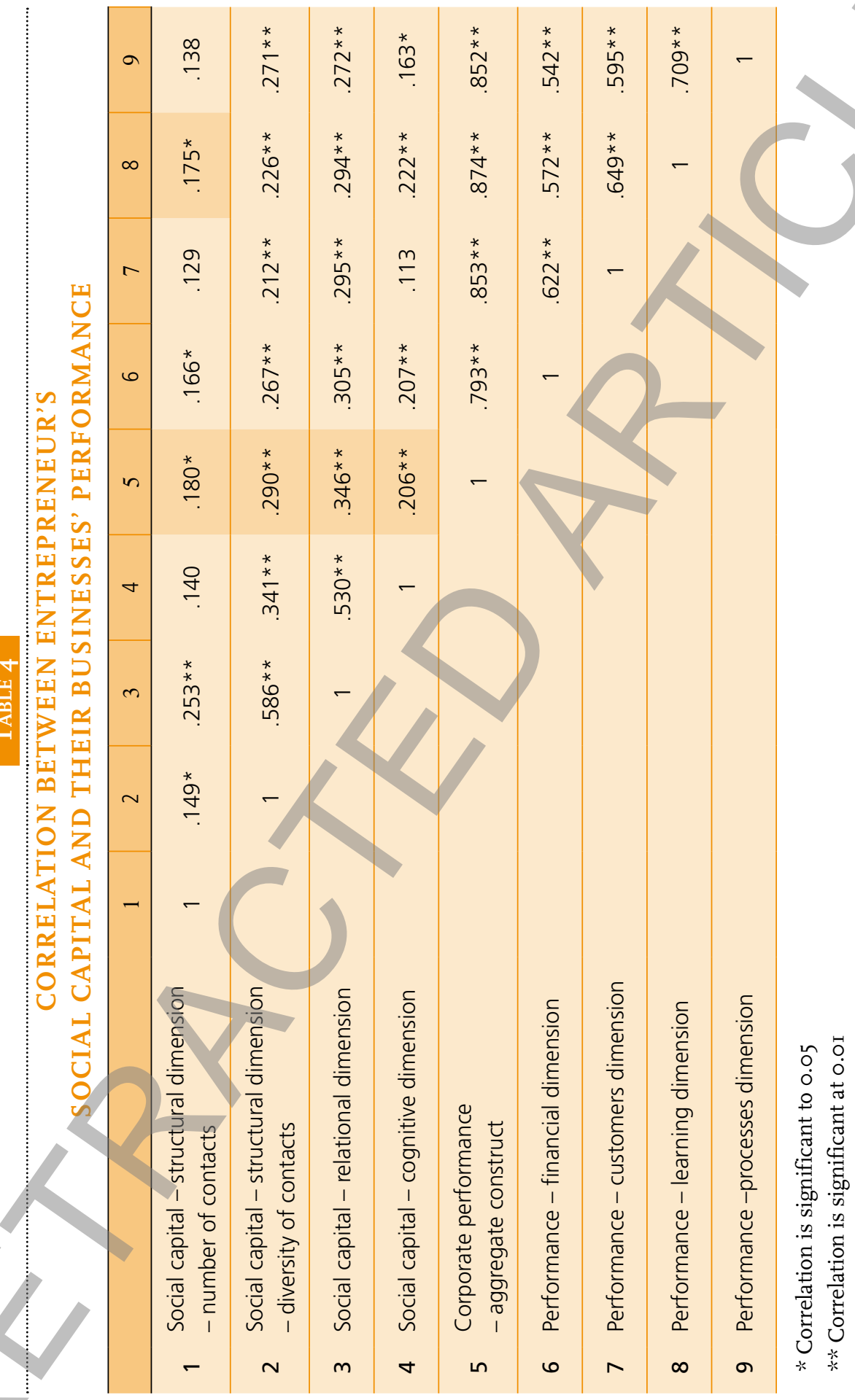

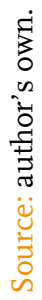




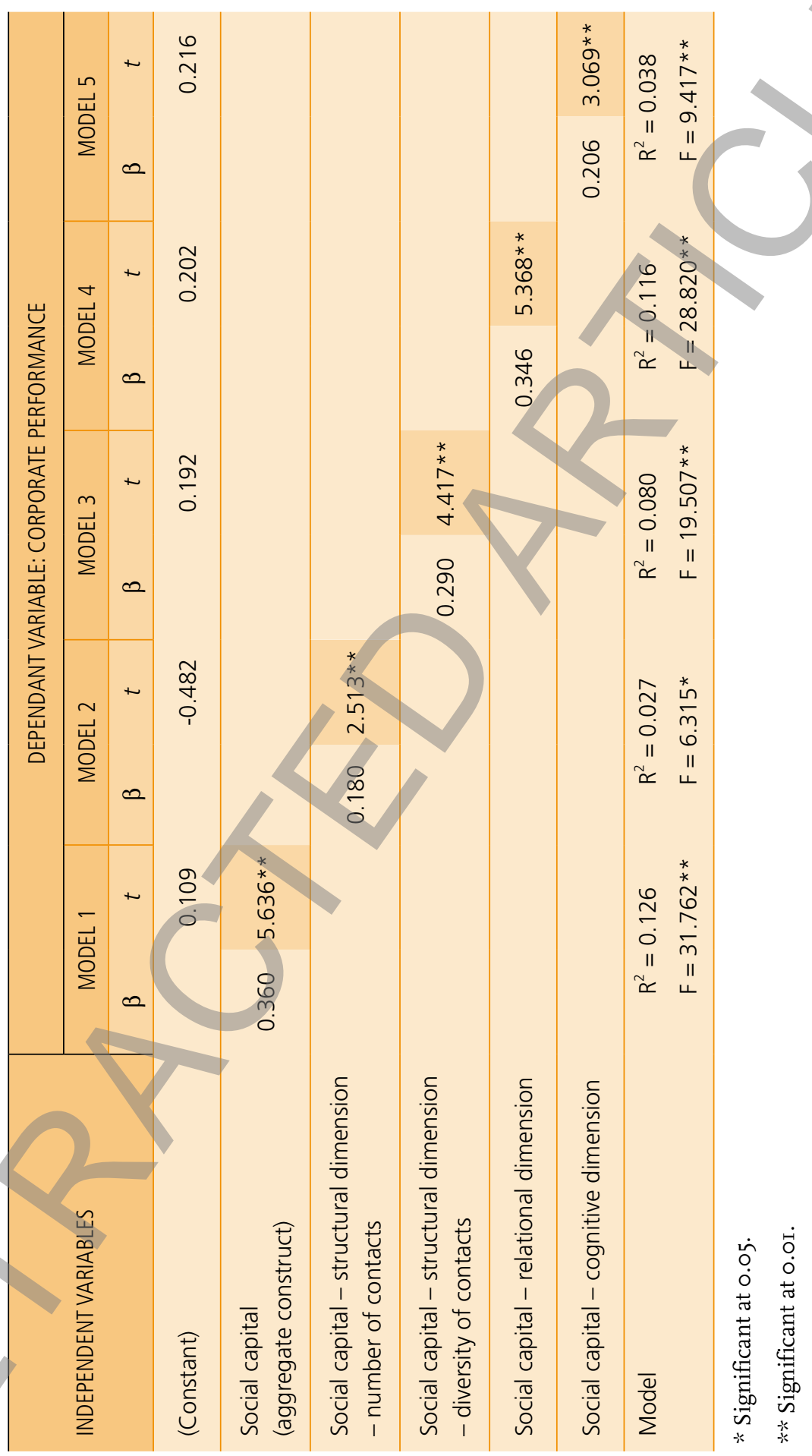


In analyzing correlation, a positive relation is noticed between the number of contacts an entrepreneur has and his/her company's performance (.I80, p < .05). There is also a positive relation between the diversity of the entrepreneur's contacts and his/her company's performance $(.290, \mathrm{p}<$. . I $)$. Models 2 and 3 of the regression analysis, which analyze the influence of both variables on the company's performance, also present statistically significant results $(\beta$ o.I80 e $\beta$ $0.290, \mathrm{p}<. \mathrm{OI})$, confirming hypotheses Hia and Hib.

For further analysis of the importance of an entrepreneur's contacts number to the organizational performance, the respondents were divided in four groups, according to the number of contacts (Table 6):

\section{TABLE 6}

\section{CATEGORIES OF ENTREPRENEURS BASED ON} THE NUMBER OF CONTACTS

\begin{tabular}{lccc}
\hline Number of contacts & Category & Frequency \\
\hline Up to 4 contacts & 1 & 65 \\
\hline Between 4 and 6 contacts & 2 & 50 \\
\hline Between 6 and 10 contacts & 3 & 38 \\
\hline Above 10 contacts & 4 & 44 \\
\hline
\end{tabular}

Source: author's own.

Comparing the previously categorized companies' performance, there is a statistically relevant difference $(\mathrm{p}<$. . I) between the entrepreneurs classified in the first and in the fourth groups. Compared to the entrepreneurs with up to four contacts inside the network, those who discuss strategic aspects with more than Io contacts present better performances. This result reinforces the relevance of the structural dimension of social capital to the organizational performance, as suggested by Uzzi and Gillespie (2002), McFadyen and Cannella Jr. (2004), and Smith, Collins and Clark (2005).

Executing the same analysis according to the four performance dimensions (finances, customers, learning, and processes), there are significant differences $(\mathrm{p}<. \mathrm{OI})$ in learning dimension. Entrepreneurs with more contacts have better learning performances. This result is in accordance with Holmqvist's argument (2003) that an entrepreneur's developing of a social network enables information and knowledge exchange, and that horizontal networks are spaces to share practice and experience on how to run and improve the businesses. This information flow can be used to develop the business and bring better performances. 
In addition to the number of contacts, the structural dimension of social capital includes the diversity of contacts, i.e., the diversity of knowledge, information and skills the contacts have. The bigger the diversity, the bigger the chances to get access to different knowledge that can be useful for the business. A small, diverse social network can have more advantages than a big, homogeneous network, in which knowledge and information are redundant. This argument generated the second research hypothesis, and the empirical results can be seen in Tables 4 and 5 .

Hypothesis 2: The relational dimension of an entrepreneur's social capital is positively related to his/her business' performance.

Correlation analysis shows that the quality of the relationships an entrepreneur has with his/her contacts is positively related to the company's performance $(.346, \mathrm{p}<. . \mathrm{oI})$. Also regression analysis model 4 (Table 5) confirms the positive influence of this dimension on the company's performance $(\beta \circ .346, \mathrm{p}<. \mathrm{oI})$, making hypothesis 2 acceptable. This dimension consists on elements such as trusting in the partners and in their competence, and believing that they will pass strategic information and will not act opportunistically. When relationships are strong, there's a bigger chance that the shared resources be strategic and can be used in favor of the business.

The third dimension of social capital involves the existence of common objectives and vision among the actors of a social network, as proposed by Inkpen and Tsai (2005), and Tsai and Ghoshal (I998). The social capital theory affirms that, just as the quality of the relationships, the cognitive alignment between the actors also influences their willing to exchange resources, which may affect the companies' performance.

Hypothesis 3: The cognitive dimension of an entrepreneur's social capital is positively related to his/her business' performance.

The researcher also verified a positive correlation between the cognitive dimension of social capital and a company's performance $(.206, \mathrm{p}<0,0 \mathrm{I})$. Furthermore, regression analysis model 5 confirms the influence of the independent variable on the company's performance $(\beta$ o.206, p < . oI). Therefore, Hypothesis 3 is acceptable. Entrepreneurs who notice cognitive similarities with their contacts - such as similar line of thought, objectives, and shared visions - have a better image of those contacts, and tend to trust that they won't act opportunistically. Consequently, there is a bigger probability of knowledge and information exchange among the entrepreneurs, compared to when there is low cognitive similarity. All those factors lead to resources and information exchange, which, in turn, improves the corporate performance. 


\subsection{SOCIAL CAPITAL AND THE ACCESS TO INFORMATION}

To better understand the role of social capital in horizontal networks, the respondents were asked about their level of access to information in six categories: suppliers, competitors, work practices that can improve the business, consumer market, legislation, and innovative products, services and processes. In general, entrepreneurs associated to networks have access to intermediary to high levels of information and knowledge considered important to the development of their businesses (Graphic I). The highest exchange of information concerns suppliers, given that wholesale companies networks negotiate with suppliers and pass the information to their associates. Wholesale companies' main goal inside networks is exactly to obtain bulk discounts when negotiating with suppliers.

\section{GRAPHIC I}

\section{LEVEL OF ACCESS TO INFORMATION}

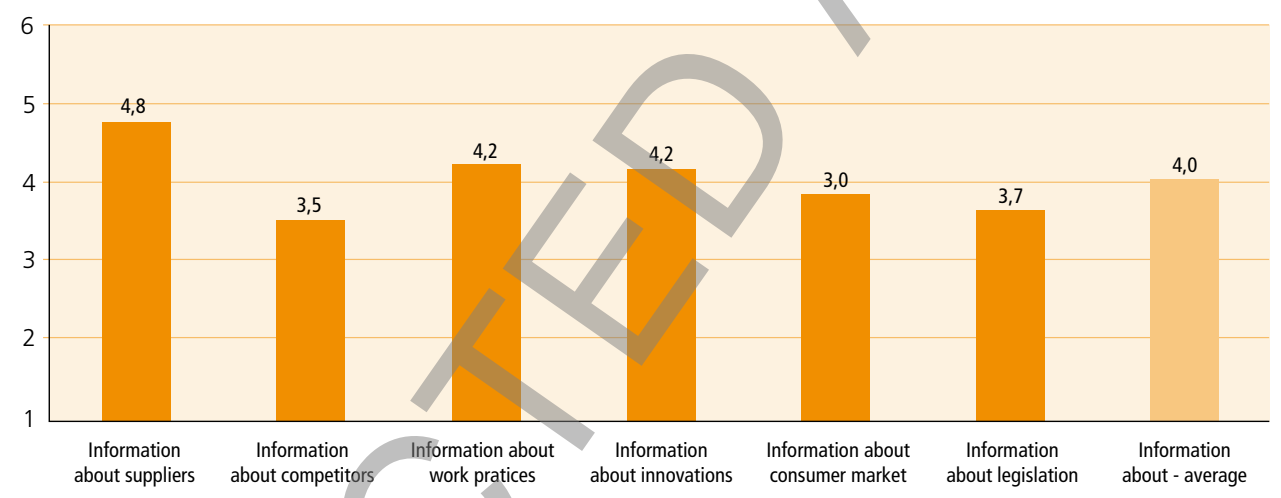

Source: author's own.

In performing correlation analyses, it was verified that the three dimensions of social capital are positively related to the level of access to information: the number of contact an entrepreneur has inside a network (.297, p <.oI), the quality of his/her relationships (.42I, $\mathrm{p}<. \mathrm{OI})$, and the similarity in their objectives $(.287, \mathrm{p}<. \mathrm{OI})$. Thus, the bigger the entrepreneur's social capital, the higher the level of access to information he has, which can be used to potentialize his/her company's performance.

An analysis of the variance indicates that entrepreneurs with more contacts (Chart 2) also have access to more information in the presented categories $(\mathrm{p}<$. . I $)$. However, according to McFadyen and Cannella Jr.'s studies (2004), the relation between the number of contacts and the level of access to information is 
probably non-linear. There is a limit in the number of contacts one can maintain and develop, above which the time and energy costs to manage the relations become higher than the resources that can be accessed. As new contacts are added to the network, the cost to develop these relationships can surpass the benefits.

Companies cooperating for less time also presented less access to information. This result is in accordance with affirmations made by McFadyen and Cannella Jr. (2004), who state that relationships, just as the volume of information exchange among the individuals, take time to develop. Developing strong relationships and accessing restricted information and knowledge may take time, so much that a longer participation in a network facilitates the sharing of values, vision and, as a consequence, informational resources. Companies that cooperate for more time can be favored by the development of common norms and values, leading to a bigger disposition to share information.

\section{DISCUSSION}

Based on the results of the empiric research, a horizontal network formally constituted can be considered an important environment for the development of entrepreneurs' social capital. In the network, the entrepreneur has the opportunity to interact with other entrepreneurs from the same segment that have different knowledge, valuable information and possibly similar problems. For many of them it would be hard to establish those relationships outside that network or to have access to the same information through external contacts. This social capital, stimulated by the network environment, can turn into other forms of capital and into a good corporate performance (ADLER; KWON, 2002).

Even though the horizontal networks are created as universal networks (TODEVA, 2006) where all actors have the opportunity to have access with one another, in practice, each entrepreneur create his/her own social relations network. Within these networks, they exchange information and knowledge about strategies, competitors, and work and process practices that can be introduced by an entrepreneur in his/her company, as predicted by social capital researchers (NAHAPIET; GHOSHAL, I998; ADLER; KWON, 2002; INKPEN; TSANG, 2005). As one can see from the results of the empiric research, this social network - which constitutes the entrepreneur's social capital in the network - is significantly smaller than the formal network because, differently from contractual relations, social relations need to be built and managed in order to generate benefits.

All the proposed hypotheses to test the relation of the dimensions of social capital with the companies' performances were accepted. The positive influence 
of an entrepreneur's number of contacts on the business performance confirm results from other studies held in different contexts, such as the ones from Ahuja (2000), McFadyen and Cannella Jr. (2004), and Smith, Collins and Clark (2005). More contacts implies potential access to more knowledge, without forgetting other important elements of social capital such as the diversity of contacts and the strength of the relationships. The results confirm the influence of the diversity of contacts (structural dimension) and the strength of the relationships (relational dimension) on corporate performance. Contacts that have diverse knowledge are valuable because they circulate non-redundant knowledge within a network. The heterogeneity of resources the contacts have (INKPEN; TSANG, 2005) and the quality of the relationships can open access to strategic resources (LIAO; WELSCH, 2003) to be converted into corporate performance.

Strong relationships require time investment, contact frequency and trust development. As pointed out by Leana and Pil (2006), entrepreneurs who achieve stronger interpersonal relationships have more chances to access strategic information from these contact, or have an earlier access to them, which can be used in favor of their businesses. Though entrepreneurs from the same network are usually not direct competitors - due to the criteria to enter the network -, the information flow tends to be influenced by the quality of relationships.

As the network provides interaction spaces, time offers the opportunity to tighten ties and develop relationships, as stated by McFadyen and Canella Jr. (2004). It is easier to share strategic information with closer contacts than with unknown people who can use them opportunistically. It means that, even though two entrepreneurs may have the same number of contacts (or even the same contacts), the emotional and personal relationships are a determining factor for the exchanges to happen (NAHAPIET; GHOSHAL, I998). Therefore, the horizontal network management is responsible for creating opportunities for the entrepreneurs to interact, broaden their relationships, and exchange knowledge. Network gatherings, business meetings, technical visits and participation in fairs and courses are some of the opportunities created by the network that can facilitate the development of interpersonal relationships.

The cognitive dimension of social capital also revealed to have a positive influence on corporate performance, but less expressively than relational dimension. Cognitive dimension analyses the degree of sharing of goals and meanings amongst the contacts of a social network. The argument is that actors with cognitive proximity tend to exchange more (NAHAPIET, 2008). Proximity makes a person see the other as someone with similar goals and, therefore, with no interest in acting opportunistically. However, excessive cognitive proximity among participants of a network can lead to bad results. If the actors share similar logics, there is a risk that the network will get stuck, leading to a limitation of new kno- 
wledge circulation and, ultimately, to a lack of motivation and interest from the associates, causing many of them to leave.

The study also confirms the multidimensionality of the social capital construct, as proposed by Nahapiet and Ghoshal (I998), and reinforces the importance of the quantity of contacts, the diversity of contacts, the relationships' strength, and the presence of cognitive similarities in order for information to be exchanged, and for performance to be improved. As stated by Nahapiet and Ghoshal (I998), and Inkpen and Tsang (2005), contacts with different profiles and knowledge make it possible to access non-redundant, complimentary knowledge. Strong relationships, in turn, make it possible to access strategic information or to have early access to information and knowledge, according to Inkpen and Tsang (2005), and Leana and Pil (2006). Thus, the entrepreneurs that have contacts with diverse profiles and are able to establish strong relationships are more likely to potentialize their performance.

The empiric research also showed a positive relation between entrepreneurs' social capital and their level of access to information. This conclusion is important because it shows that social capital not only provides entrepreneurs with potential access to information and knowledge, but also that the entrepreneurs effectively absorb that knowledge and positively apply it in their companies.

\section{FINAL CONSIDERATIONS}

Through a quantitative research performed with entrepreneurs associated to horizontal networks, this article analyzed the influence of social capital on corporate performance. The study was set on the premise that an entrepreneur's social capital gives him access to resources - information and knowledge - that other entrepreneurs have, and that can be used to potentialize the company's performance. Four research hypotheses were proposed in order to analyze the influence, on a company's result, of the number of contacts an entrepreneur has, the diversity in his/her contacts, the quality of relationships and the cognitive similarity.

The results show that an entrepreneur's social network is significantly smaller than the total number of participants of the horizontal network. It means that, even though the networks are created based on the assumption that every member relates to all the others, in practice each entrepreneur develops his/her own network of social relations, in which he discusses strategic aspects of the business and exchanges relevant information for his/her company.

Data analysis confirmed the research's four hypotheses, proving a positive relation between the company's performance and the number of contacts of an entrepreneur in the network, the diversity of the relations, the quality of the rela- 
tions, and the cognitive similarity between contacts. It was also verified that entrepreneurs who participate in horizontal networks have access to high levels of relevant information for their businesses, due to the social capital developed within the network. Therefore, it can be concluded that horizontal networks play an important role in the development of an entrepreneur's social capital, which, in turn, potentializes the access to relevant information and the corporate performance.

This study's main theoretical contribution is the confirmation that social capital is a factor that truly influences corporate performance, as proposed by Nahapiet and Ghoshal (I998), and Tsai and Ghoshal (I998). It specifically reveals that horizontal networks are important environments to develop entrepreneurs' social capital, as they gather individuals with different profiles and knowledge, creating an informational flow that can enhance corporate performance.

The managerial contribution of this study is that it indicates that network managers can stimulate the development of entrepreneurs' social capital. Promoting meetings in which entrepreneurs can create and strengthen new relationships is one of the forms of stimulation of social capital. Not only the number and diversity of contacts increase - structural dimension -, but also the quality of the relationships and the cognitive similarity among the participants, fomenting the development of common objectives and shared visions.

\section{A INFLUÊNCIA DO CAPTTAL SOCIAL PARA O DESEMPENHO EMPRESARIAL: UMA ANÁLISE NO CONTEXTO DAS REDESHORIZONTAIS DE EMPRESAS}

\section{RESUMO}

Com base nos argumentos de Nahapiet e Ghoshal (I998), o presente artigo analisa a relação entre o capital social de empresários participantes de redes horizontais e o desempenho de suas empresas. Por meio de uma pesquisa com 2I8 empresários de 34 diferentes redes horizontais de empresas, verificou-se que o número de contatos de um empresário dentro da rede, a diversidade, qualidade das relações e a semelhança cognitiva influenciam positivamente o desempenho da sua empresa. Os resultados revelam ainda que empresários participantes de redes horizontais têm acesso a níveis altos de informações relevantes para seu negócio, a partir do capital social desenvolvido dentro da rede. A principal contribuição teórica do artigo é a confirmação da relevância do capital social do empresário para o desempenho de sua empresa, reafirmando no contexto das redes interorganizacionais estudos de Ahuja (2000), McFadyen e Cannella (2004), 
Smith, Collins e Clark (2005), Tsang (2005) e Liao e Welsch (2003). Como contribuição gerencial, os resultados mostram que gestores de redes horizontais podem criar mecanismos para estimular o desenvolvimento do capital social dos empresários, promovendo a criação e fortalecimento de laços, com consequências positivas para o resultado das empresas.

\section{PALAVRAS-CHAVE}

Capital social; Redes interorganizacionais; Redes horizontais de empresas; Cooperação empresarial; Desempenho.

\section{LA INFLUENCIA DEL CAPITAL SQCIAL EN LA \\ RENDIMENTO DEL NEGOCIO: UN ANÁLISIS EN EL CONTEXTO DE LAS REDES HORIZONTALES DE} EMPRESAS

\section{RESUMEN}

Con base en los argumentos de Nahapiet y Ghoshal (i998), este artículo analiza la relación entre el capital social de los empresarios que participan en redes horizontales entre organizaciones en el desempeño de sus empresas. Una encuesta realizada a 2I8 empresarios de 34 redes empresariales horizontales, encontró que el número total de contactos de un empresario dentro de la red, la diversidad, la calidad de las relaciones y la similitud cognitiva influyen positivamente en el desempeño de la empresa. Los resultados también muestran que los empresarios que participan en redes horizontales tienen acceso a los altos niveles de información relevante para sus negocios, desde el capital social desarrolladas dentro de la red. La principal contribución teórica de este estudio es que confirma la relevancia dẻl capital social en el desempeño del negocio, lo que confirma, en el contexto de las redes entre organizaciones, los estudios realizados por Ahuja (2000), McFadyen y Cannella (2004), Smith, Collins y Clark (2005), Tsang (2005) y Liao y Welsch (2003). Como una contribución a una práctica de gestión, los resultados muestran que los administradores de red pueden crear mecanismos para fomentar el desarrollo del capital de los emprendedores sociales, promoviendo la creación y fortalecimiento de los lazos, con consecuencias positivas para el rendimiento empresarial. 


\section{PALABRAS CLAVE}

Capital social; Redes inter-organizacionales; Redes horizontales de negocio; Cooperación empresarial; Rendimiento organizacional.

\section{REFERÊNCIAS}

ADAM, C. R. Proposição de indicadores para avaliação de desempenho de redes de cooperação. (Dissertação de mestrado)-Programa de Pós-Graduação em Engenharia de Produção, Universidade Federal de Santa Maria (UFSM), Santa Maria, 2006.

ADLER, P. S.; KWON, S. W. Social capital: prospects for a new concept. Academy of Management Review, v. 27, n. I, p. I7-40, 2002.

AHUJA, G. Collaboration Networks, structural holes, and innovation: A longitudinal study. Administrative Science Quarterly, n. 45, p. 425-455, 2000.

AMARAL, S. A. T.; RI, L. D. Capital social, democracia e desenvolvimento. Perspectivas em Gestão \& Conhecimento, v. I, n. 2, p. I36-I49, jul.-dez. 201 I.

BURT, R. S. The contingent value of social capital. Administrative Science Quarterly, v. 42, n. 2, p. 339-365, I997.

CASTELL, M. A sociedade em rede. São Paulo: Paz e Terra, I999.

COLEMAN, J. S. Social capital in the creation of human capital. American Journal of Sociology, n. 94, p. 95-I20, I988.

DESS, G. G.; ROBINSON, R. B. Measuring organizational performance in the absence of objective measures: the case of the privately-held firm and conglomerate business unit. Strategic Management Journal, v. 5, p. 265-273, I984.

GARGIULO, M.; BANASSI, M. Trapped in your own net? Network cohesion structural holes, and adaptation of social capital. Organization Science, n. II, p. I83-196, 2000.

GELETKANYCS, M. A.; HAMBRICK, D. C. The external ties of top executives: implications for strategic choice and performance. Administrative Science Quarterly, n. 42, p. 654-68I, I997.

GRANOVETTER, M. The strength of weak ties. American Journal of Sociology, v. 78, n. 6, p. 1360I380, I973.

HAIR, J.; ANDERSON, R.; TATHAM, R.; BLACK, W. C. Análise multivariada de dados. 5. ed., Porto Alegre: Bookman, 2005.

INKPEN, A. C.; TSANG, E. W. K. Social capital, networks, and knowledge transfer. Academy of Management Review, v. 30, n. I, p. I46-I65, 2005.

KALE, P.; SINGH, H.; PERLMUTTER, H. Learning and protection of proprietary assets in strategic alliances: Building relational capital. Strategic Management Journal, v. 2I, n. 3, p. 2I7-237, 2000. LARSON, A.; STARR, J. A. A network model of organization formation. Entrepreneurship: Theory and Practice, v. I7, p. 5-15, I993.

LEANA, C. R.; PIL, F. K. Social capital and organizational performance: Evidence from urban public schools. Organization Science, v. I7, n. 3, p. 353-366, 2006.

LESSER, E. L. Leveraging social capital in organizations. In: LESSER, E. L. (Org.). Knowledge and social capital: Foundations and applications. Boston: Butterworth Heinemann, p. 3-16, 2000. 
LIAO, J.; WELSCH, H. Social capital and entrepreneurial growth aspiration: a comparison of technology and non-technology-based nascent entrepreneurs. Journal of High Technology Management Research, v. I4, 2003, p. I49-170.

MALHOTRA, N. K. Pesquisa de marketing: Uma orientação aplicada. Porto Alegre: Bookman, 200 . MAYER, R. C.; DAVIS, J. H.; SCHOORMAN, F. D. An integrative model of organizational trust. Academy of Management Review, v. 20, n. 3, p. 709-734, 2005.

McFADYEN, M. A.; CANNELLA Jr., A. A. Social capital and knowledge creation: diminishing returns of the number and strength of exchange relationships. Academy of Management Journal, v. 47, n. 5, p. 735-746, 2004 .

MJOEN, H.; TALLMAN, S. Control and performance in international joint ventures. Organization Science, v. 8, n. 3, p. 257-274, I997.

MOHR, J.; SPEKMAN, R. Characteristics of partnership success: Partnership attributes, communication behavior, and conflict resolution techniques. Strategic Management Journal, v. I5, n. 2, p. I35-152, I994.

MU, J.; PENG, G.; LOVE, E. Interfirm networks, social capital, and knowledge flow. Journal of Knowledge Management, v. I2, n. 4, p. 86-100, 2008.

NAHAPIET, J. The role of social capital in inter-organizational relationships. In: CROPPER, S.; EBERS, M.; HUXHAM, C.; RING, P. S. (Org.). Inter-organizational relations. Oxford: Oxford University Press, 2008, p. 580-606.

NAHAPIET, J. J.; GHOSHAL, S. Social capital, intellectual capital, and the organizational advantage. Academy of Management Review, v. 23, n. 2, p. 242-266, I998.

NOHRIA, N.; ECLES, R. Networks and organizations: structure, form and action. Boston: Harvard Business School Press, I992.

OSBORNE, J. Improving your data transformations: Applying the Box-Cox transformation. Practical Assessment, Research \& Evaluation, v. I5, n. I2, 2010.

PUTNAM, R. Comunidade e democracia: a experiência da Itália moderna. Rio de Janeiro: Editora FGV, 2002.

SANTAOLÀRIA, R. P.; DIÉGUEZ, E. D. Construcción y análisis de escalas. In: MANGIN, J. P. L.; MALLOU, J. V. Analisis multivariable para las ciencias sociales. Madrid: Pearson Educación, 2005. p. $43-89$.

SANTOS, L. G. A.; ROSSONI, L; MACHADO-DA-SILVA, C. L. Condicionantes estruturais dos relacionamentos intraorganizacionais: uma análise da influência sobre relações de comunicação e decisão. RAM, Revista de Administração do Mackenzie, v. I2, n. I, p. I39-I68, jan.-fev., 201 I.

SANTOS, M. J. N.; SILVA, R. R. A importância da responsabilidade social corporativa para a potenciação do capital social em pequenas e médias empresas. Revista de Ciências da Administração, v. I2, n. 27, p. 190-207, maio-ago. 2010.

SEBRAE - Serviço Brasileiro de Apoio às Micro e Pequenas Empresas. Mapeamento das centrais e redes de negócio. 2008. Disponível em: <http://www.sebrae.com.br/customizado/acesso-a-mercados/sebrae-mercado/centrais-de-negocios>. Acesso em: 30 nov. 2010.

SEDAI. Secretaria do Desenvolvimento e Assuntos Internacionais. Programas e Ações do Governo. 20I0. Disponível em: <http://www.sedai.rs.gov.br/redes_cooperacao.php\#mapa >. Acesso em: 28 out. 2010 . 
SMITH, K. G.; COLLINS, C. J.; CLARK, K. D. Existing knowledge, knowledge creation capability, and the rate of new product introduction in high-technology firms. Academy of Management Journal, v. 48 , n. 2, p. 346-357, 2005 .

TODEVA, E. Business Networks: Strategy and Structure. Londres: Toutledge, 2006.

TSAI, W.; GHOSHAL, S. Social capital and value creation: The role of intrafirm networks. Academy of Management Journal, v. 4I, n. 4, p. 464-476, I998.

UZZI, B. The sources and consequences of embeddedness for the economic performance of organizations. American Sociological Review, n. 61, p. 674-698, 1996.

UZZI, B.; GILLESPIE, J. J. Knowledge spillover in corporate financing networks: Embeddedness and the firm's debt performance. Strategic Management Journal, v. 23, n. 7, p. 595-618, 2002.

VERSCHOORE, J. R.; BALESTRIN, A. Ganhos competitivos das empresas em redes de cooperação. Revista de Administração da USP - RAUSP, v. I, n. I, p. I-2I, $2008 \mathrm{~b}$.

WEGNER, D.; MAEHLER, A. E. Desempenho de empresas participantes de rede interorganizacionais: analisando a influência do capital social e da capacidade absortiva. Revista Gestão e Planejamento, Salvador, v. I3, n. 2, p. I9I-2II, maio-ago. 2012. 